\title{
Morphological and molecular features of stain fungi infecting rubberwood (Hevea brasiliensis)
}

\author{
DODI NANDIKA ${ }^{1, \boldsymbol{v}}$, ARINANA ${ }^{1}$, ALI BIN ABITHALIB SALMAN ${ }^{2}$, JULIA YONIPI PUTRI $^{1}$ \\ ${ }^{1}$ Department of Forest Products, Faculty of Forestry and Environment, Institut Pertanian Bogor. Jl. Ulin, Kampus IPB Dramaga, Bogor 16680, West Java, \\ Indonesia. Tel.: +62-251-8621677, `email: dodina@apps.ipb.ac.id, juliayonipi.putri18@gmail.com \\ ${ }^{2}$ Department of Biology, Faculty of Mathematics and Natural Sciences, Institut Pertanian Bogor. Jl. Agatis, Kampus IPB Dramaga, Bogor 16680, West \\ Java, Indonesia
}

Manuscript received: 7 November 2021. Revision accepted: 20 November 2021.

\begin{abstract}
Nandika D, Arinana, Salman ABA, Putri JY. 2021. Morphological and molecular features of stain fungi infecting rubberwood (Hevea brasiliensis). Biodiversitas 22: 5408-5416. In the southeast Asia region, particularly Indonesia, Thailand, and Malaysia, rubberwood (Hevea brasiliensis Muell. Arg.) has been widely used as a raw material in various industries particularly furniture manufacturing. However, rubberwood is highly susceptible to fungal attack due to its lack of heartwood formation. A laboratory study was conducted to investigate the morphological and molecular features of stain fungi infecting rubberwood. A total of five isolates of stain fungi belonging to three genera were identified based on internal transcribed spacer (ITS) and morphological features. All isolates belong to Order Eurotiales with each genus being Paecilomyces, Aspergillus, and Penicillium. The highest growth rate on wood samples was shown by Aspergillus chevalieri section Aspergillus and Paecilomyces maximus or P. formosus with values of $86.57 \%$ and $86.22 \%$, respectively. All of the stain fungi genera caused varied level of discoloration on wood samples with dark grayish and very dark grayish as the more frequent color found. Quantitatively, the highest discoloration was shown by A. chevalieri section Aspergillus $(\Delta \mathrm{E}=27.60)$ and $P$. maximus or P. formosus $(\Delta \mathrm{E}=16.69)$. These species can be considered as newly stain fungi recorded infecting rubberwood in Indonesia. In addition, discoloration caused by these two stain fungi was the worst.
\end{abstract}

Keywords: Characterization, CIELab method, ITS region, stain fungi, wood discoloration

\section{INTRODUCTION}

The rubber tree (Hevea brasiliensis Muell. Arg.) is one of the hardwood species that are native to the tropical rainforest, Brazil. This plant is an essential crop-producing natural rubber cultivated in southeast Asia (Oktavia et al. 2011) and initially planted in Indonesia for rubber sap production in 1864. Currently, Indonesia has a total rubber plantation area of almost 3.67 million Ha (Oktavia et al. 2021). The planted rubber tree produces latex for tires, adhesives, and other products. After a certain number of years, a rubber tree produces too small an amount of latex, and the tree must be replaced with a new one. Therefore, a huge number of woods from the old rubber trees have been used for various purposes. The attractive properties of rubberwood are its creamy color and good working properties (Junior et al. 2015; Teoh et al. 2011) with 0.6 $\mathrm{g} / \mathrm{cm}^{3}$ in density, 1.4-1.9 MPa in tensile strength, $6000 \mathrm{~N}$ in hardness, $103 \mathrm{MPa}$ in modulus of rupture (MOR), and $9900 \mathrm{MPa}$ in modulus of elasticity (MOE) (Riyaphan et al. 2015).

In the South East Asia region, particularly Indonesia, Thailand, and Malaysia, rubberwood has been widely used as a raw material in various industries such as furniture manufacturing, kitchenware and wooden toy industries (Lim et al. 2003). This rubberwood based industries plays an important role in generating foreign exchange for the countries since the products are mostly exported to other countries (Statistics Indonesia, The Republic of Indonesia
2020). Moreover, this industry also employs a significant number of laborers. However, rubberwood is highly susceptible to fungal attack due to its lack of heartwood formation (Ho 1999; Priyadarshan 2011). According to George (1985) wood staining fungi can seriously attack rubberwood as soon as within 1 day of felling. Due to the fungal attack, rubberwood experienced discoloration causing a significant decrease in its aesthetical value. An example of stain fungi is Botryodiplodia theobromae, which occurs together with the surface mold Aspergillus sp. and Penicillium spp. also cause considerable loss of aesthetical value of attacked wood. Susceptibility of rubberwood to stain fungi and mould colonization on its surface is considered a major concern for furniture and wooden toy manufacturers. The tropical climate, characterized by temperature above $25^{\circ} \mathrm{C}$ and humidity of $80-100 \%$ in Indonesia, imposes challenging conditions for protecting rubberwood from stain fungi attacks. This environmental condition is suitable for the growth of various wood inhabiting fungi, including stain fungi. (Drewello and Weissmann 1997; Müller et al. 2001). The fungi especially made colonization in non-durable wood surfaces in the rainy season where various nutrients produce water vapor in the air (Pinto et al. 2019). In 2018, economic loss due to stain fungi attack on rubberwood as raw material in furniture industry in Indonesia reached almost USD 15.246 million (Salman 2020). This value is predicted to increase significantly since most of Indonesian furniture industries prefer to use the light color lumber, 
including rubberwood for their production processes without any sufficient control techniques.

Stain fungi is filamentous fungi that causes discoloration on wood surface like blue, greyish, green and black. Colonization of the fungi initiates the mineralization process occurs on the wood surface, leading to discoloration. Valiante et al. (2016) argued that discoloration is caused by pigmentation on the hyphae or melanin synthesis on the conidia during sporulation process. Previous studies reported that three stain fungi species were identified from rubberwood, which were Aspergillus niger, Aspergillus flavus, and Penicillium citrinum (Oldertrøen et al. 2016). Meanwhile, Salman et al. (2020) reported that at least there were two stain fungi isolated from air dried rubberwood which will be processed for furniture products in West Java Province, Indonesia, which were Aspergillus aflatoxiformans and A. foetidus. In addition, Razali et al (2016) reported that there were seven isolates obtained from rubberwood and classified into three groups, namely Fusarium equiseti, Mucor irregularis, and Lasiodiplodia theobromae.

However, there is a lack of scientific information regarding characteristics of stain fungi attacking rubberwood in furniture industries in Indonesia, including their molecular as well as morphological features. This leads to inadequate strategic development and application as well as prevention techniques of stain fungi attacks on rubberwood, especially in the furniture industries in Indonesia. Therefore, the present study investigated the morphological and molecular features of stain fungi isolated from Indonesian rubberwood industry. This present work also aimed to isolate and characterize the stain fungi species that dominantly attack rubberwood used in furniture industry. Furthermore, this study is considered to contribute in the development of proper method of stain fungi control in the related wood industries.

\section{MATERIALS AND METHODS}

\section{Rubberwood sample collection}

Air-dried rubberwood as furniture product components were obtained from one of the biggest furniture industries in Bekasi, West Java Province, Indonesia. The furniture industry prepared wood from natural rubber trees that no longer produce latex after 25 years, obtained from Palembang, South Sumatra Province, Indonesia. The rubberwood was kept in the dark plastic bags and taken to laboratory for further laboratory procedures.

\section{Isolation of stain fungi for significant growth}

The air-dried rubberwood were cut into wood samples sized $2 \times 2 \times 1 \mathrm{~cm}$ and soaked in aquadest for 24 hours and then treated with surface sterilization based on Hughes et al. (2018). The wood samples were soaked in sterile aquadest for two minutes and shaken occasionally. This process was conducted five times and then passed over fire slightly (Sudirman 2018, pers. com). The wood samples were incubated in the petri dish $(\varnothing=9 \mathrm{~cm})$ using potato dextrose agar (PDA) medium for seven days $\left(28 \pm 2^{\circ} \mathrm{C}\right.$,
$74.6 \pm 5 \% \mathrm{RH})$. Hyphae as well as spores of fungal colonies that grew on each wood sample were cultivated and incubated in the petri dish $(\varnothing=9 \mathrm{~cm})$ using PDA medium $\left(28 \pm 2{ }^{\circ} \mathrm{C}, 74.6 \pm 5 \% \mathrm{RH}\right)$ for purification process. After seven days of incubation, the diameter of stain fungi colony grown from each isolate was then determined.

For selection process, wood samples made from air dried rubberwood were prepared with size $5 \times 2 \times 0.5 \mathrm{~cm}$ and sterilized in an autoclave at $121^{\circ} \mathrm{C}$ for 15 minutes. Sterile wood samples and mycelium of each stain fungi isolate were put in petri dish $(\varnothing=9 \mathrm{~cm})$ and incubated for four weeks $\left(28 \pm 2^{\circ} \mathrm{C}, 74.6 \pm 5 \% \mathrm{RH}\right)$ based on ASTM D 4445-03 (2003) and Aleinikovas et al (2021). Later, the wood samples were removed and dried up at $60^{\circ} \mathrm{C}$ for three days. The growth rate (in percentage) of each isolate on wood samples was then determined based on the ratio. of its colony growth's coverage to the total surface area of the wood samples. The value was then converted into a scoring system according to Jantamas et al. (2013) as presented in Table 1.

\section{Morphological identification of stain fungi}

Each fungal isolate was incubated in the petri dish $(\varnothing=$ $9 \mathrm{~cm}$ ) using PDA medium for macroscopic as well as microscopic analysis. For macroscopic analysis, the isolates were cultivated in the center of PDA medium for seven days $\left(28 \pm 2{ }^{\circ} \mathrm{C}, 74.6 \pm 5 \% \mathrm{RH}\right)$. Meanwhile, for microscopic analysis the isolates were cultivated in three points on PDA for seven days $\left(28 \pm 2^{\circ} \mathrm{C}, 74.6 \pm 5 \% \mathrm{RH}\right)$ based on Thathana et al. (2017). Fungal spore and spore chain were observed under a light microscope. Macroscopic analysis includes colony's diameter as well as colony's color of the top and bottom parts, while microscopic analysis was based on the structure of generative hyphae (Diba et al. 2007).

\section{Molecular identification of stain fungi}

Molecular identification of each fungal isolate was carried out based on the analysis of internal transcribed spacer (ITS) region sequences. Specifically, the ITS regions were amplified using primer pairs ITS4 (5'TCCTCCGCTTATTGATATGC-3') and ITS5 (5'GGAAGTAAAAGTCGTAACAAGG-3'). The polymerase chain reaction (PCR) condition was reported as follows: pre-denaturation in 5 minutes at $95^{\circ} \mathrm{C}$, denaturation at $95^{\circ} \mathrm{C}$ for $45 \mathrm{~s}$, annealing at $52^{\circ} \mathrm{C}$ for 1 minute, elongation at $72^{\circ} \mathrm{C}$ for 1 minutes, post elongation at $72^{\circ} \mathrm{C}$ for 5 minutes, and cooling for $4^{\circ} \mathrm{C}$ for 5 minutes. The stages of denaturation, annealing, and elongation were carried out as many as 35 cycles (White et al. 1990).

Table 1. Scoring system of stain fungi isolate's infestation on wood sample based on its growth rate

\begin{tabular}{llc}
\hline No. & Isolate's growth rate $(\boldsymbol{\%})$ & Score \\
\hline 1 & $0 \%$ & 0 \\
2 & $0-20 \%$ & 1 \\
3 & $20-40 \%$ & 2 \\
4 & $40-60 \%$ & 3 \\
5 & $60-80 \%$ & 4 \\
6 & $80-100 \%$ & 5 \\
\hline
\end{tabular}


According to the manufacturer's protocol, the PCR amplicons were purified using $50 \mu \mathrm{L}$ TE buffer and $10 \mu \mathrm{L}$ RNAse. Finally, the purified products were delivered to $1 \mathrm{st}$ Base DNA sequencing service, Malaysia to identify gene sequences. The obtained sequences were analyzed by using Chromas Pro software version 1.7.7, followed by Basic Local Alignment Search Tool nucleotide (BLASTn) on GenBank (http://www.ncbi.nlm.nih.gov/) for fungal identification. The aligned sequences were conducted by Muscle, and phylogenetic tree was constructed by Kimura 2-parameter + Gamma distribution and Neighbor Joining (NJ) with bootstrap 1000 replicates MEGA 5.

\section{Discoloration measurement of the infected wood samples}

The CIELab method was employed to determine the discoloration of the samples due to infection of each isolate. This method involved directly measuring the values of $L, a$, and $b$ from a photograph. The photo was obtained using a stereo microscope (Olympus SZ2-ILST, from Tokyo, Japan) then analyzed with the Corel Draw X8 application (Afshari-Jouybari et al. 2011; Gahruie et al. 2017). The color of wood samples was measured using a colorimeter Konica Minolta CR-10 plus and the staining values were obtained which were indicated by the signs $L$, $a$, and $b$. $L$ represented lightness, with a value ranges from 0-100 (black to white); $a$ represented colors, with $+a$ ranges from 0-80 corresponding to red and- $a$ ranges from-80-0 corresponding to green; and $b$ represented, with $+b$ ranges from $0-70$ corresponding to yellow and- $b$ ranges from-70-0 corresponding to blue (Christie 2007). Each sample was assessed at five points, and the average values were used for the analysis. The color change $(\Delta E)$ was calculated considering CIELab method (Hunter Lab 2008), using the following equation:

$$
\Delta \mathrm{E}=\sqrt{(\Delta L)^{2}+(\Delta a)^{2}+(\Delta b)^{2}}
$$

Where: $\Delta E$ : color change; $\Delta L$ : difference in $L$ values between compared samples; $\Delta a$ : difference in $a$ values between compared samples; $\Delta b$ : difference in $b$ values between compared samples. The color change can be classified as shown in Table 2.

\section{RESULTS AND DISCUSSION}

Stain fungi isolates and their morphological characteristics

Based on the isolation process, we found five isolates of stain fungi that infected the wood samples, which were coded as $\mathrm{KrC} 1, \mathrm{KrC} 2, \mathrm{KrD} 1, \mathrm{KrD} 2$, and $\mathrm{KrE} 1$. Their macroscopic as well as microscopic appearance following the seven days-incubation on the PDA medium were presented in Figure 1.

Isolate $\mathrm{KrC} 1$ showed a light green surface in the center of the colony and was predominantly covered by white mycelia. The form of the colony was circular, and its margin was entire. In the greenish part of the colony there was exudate. The bottom of the colony consisted of two parts with different colors, the yellowish color under the green colony and the white color found in the mycelium.
Colony diameter of isolate $\mathrm{KrC} 1$ after incubation for seven days at room temperature $\left(28 \pm 2{ }^{\circ} \mathrm{C}\right)$ was $8 \mathrm{~cm}$. This isolate features a microscopic structure with hyaline and septate hyphae, fusiform chained conidia and sometimes scattered or separated, conidia size 2.42-4.32 (3.26) X 5.97-9.89 (7.06) $\mathrm{m}$, globose chlamydospore, with two or three conidiogenous (phialide) cell structures that branch from conidiophores (monoverticillate branches). The phialides were seen enlarged at the bottom and then narrowed at the ends towards the conidia. Based on its morphological form, isolate $\mathrm{KrC} 1$ was suspected to belong to the genus Paecilomyces. Paecilomyces is an anamorphic form of Byssochlamys which is characterized to have branching on the conidiophores, widening phialids on the lower front and narrow elongated ends, as well as producing ellipsoidal or cylindrical chained conidia with olive brown color (Houbraken et al. 2020). A similar finding was reported by Dong et al. (2012) who identified fungi with phylogenetic results closer to the genus Paecilomyces. The characteristics of colonies shown by this genus were rounded, dense floccose, and an entire colony margin after being grown in PDA media for seven days. Microscopically, it was observed that the conidiophores had verticillate branches, septate hyphae, hyaline, 3 to 6 phialids, and conidia chains that were fusiform or ellipsoidal in shape with a smaller size, i.e 1.8-2.1 X 2.3$2.8 \mu \mathrm{m}$. Sabernasab et al. (2019) also showed that the growth of Paecilomyces colonies reached $2.5 \mathrm{~cm}$ with a yellow colony surface after being grown in PDA media for seven days. Microscopically, this study found branching conidiophores with one or more phialids, and chain conidia with cylindrical to ellipsoidal shapes were seen measuring 3.53-6.58 (16.3) X 2.01-3.80 (2.75) $\mu \mathrm{m}$.

Different characteristics were also shown by isolate $\mathrm{KrC} 2$ with slower growth compared to other isolates. The growth diameter of this isolate only reached $2.43 \mathrm{~cm}$ after seven days of incubation at room temperature $\left(28 \pm 2{ }^{\circ} \mathrm{C}\right)$. The color of the colonies' surface is brownish with a brown exudate, while the edges of the colonies are yellowish. The bottom of the colony is yellowish with undulate margin, and the elevation of colony is flat. In addition, microscopically, we found a yellowish sac surrounding the spores namely cleistothecium with an average size of 84.83 $\mu \mathrm{m}$, while the hyaline spore with an average size of 10.45 $\mu \mathrm{m}$. These characteristics were also found by Chen et al. (2017) who reported that Aspergillus, member of "section Aspergillus", was characterized by its yellowish cleistothecia, hyaline ascospore, and in globose form.

Table 2. Color change class (Hunter Lab 2008; Hřcková et al. 2018)

\begin{tabular}{lll}
\hline Class & $\begin{array}{l}\text { Color } \\
\text { difference }\end{array}$ & Color change effect \\
\hline 1 & $\Delta \mathrm{E}<0.2$ & Invisible changes \\
2 & $0.2<\Delta \mathrm{E}<2.0$ & $\begin{array}{l}\text { Very small changes } \\
\text { Small changes (color changes visible } \\
\text { by high-quality filter }\end{array}$ \\
& $2.0<\Delta \mathrm{E}<3.0$ & $\begin{array}{l}\text { Medium (color changes visible by } \\
\text { medium-quality filter }\end{array}$ \\
4 & $3.0<\Delta \mathrm{E}<6.0$ \\
5 & $6.0<\Delta \mathrm{E}<12$ & $\begin{array}{l}\text { Big (distinct color changes) } \\
\text { Different color }\end{array}$ \\
\hline
\end{tabular}



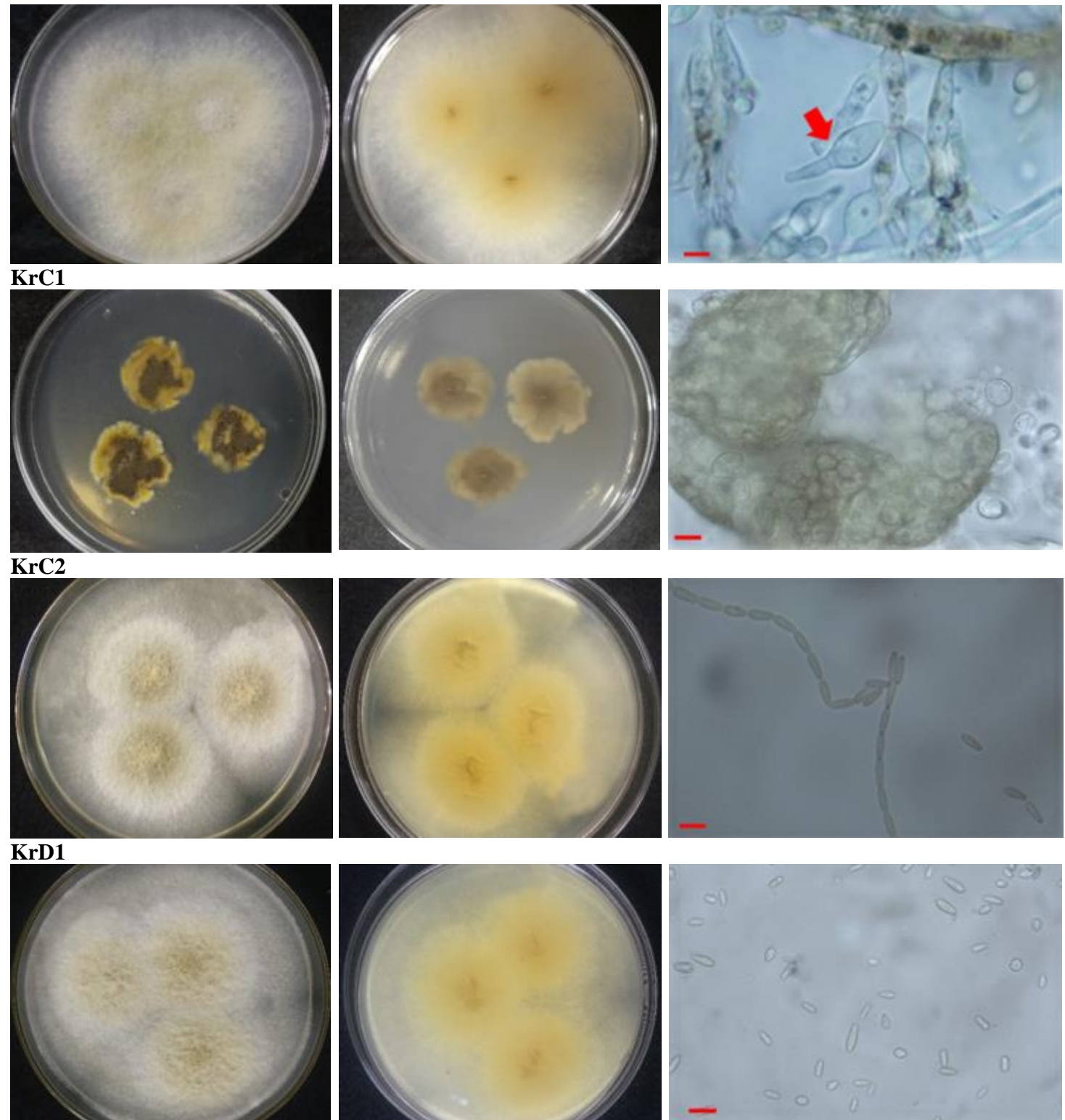

\section{KrD2}
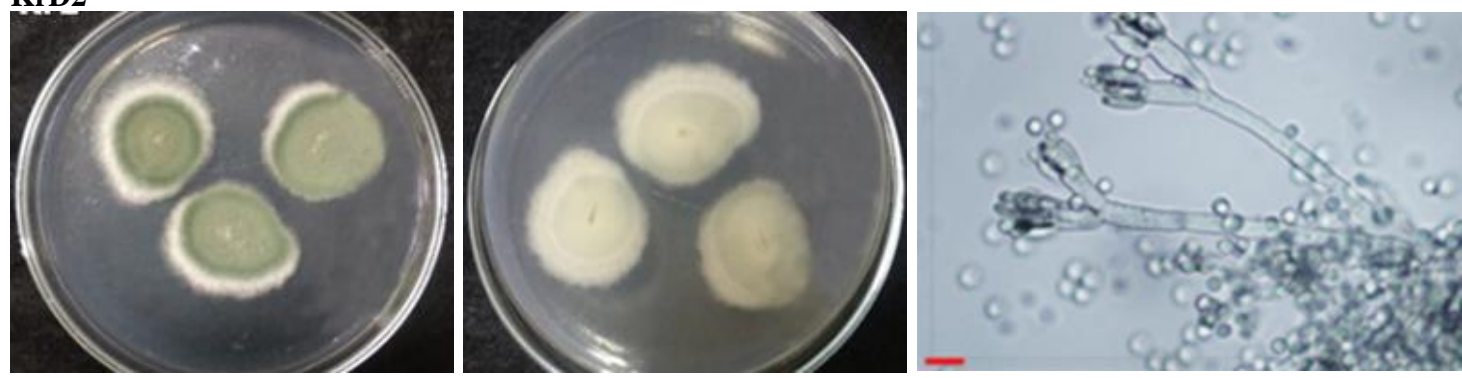

KrE1

Figure 1. Stain fungi colonies from left to right: the top view of the colony, the bottom view of the colony, and microscopic observations of the colony. The arrows indicate the shape of phyalide. Scale bar $=10 \mu \mathrm{m}$

This research also found that isolate $\mathrm{KrD} 1$ shared similar characteristics with $\mathrm{KrD} 2$, with the color of the surface of both colonies was yellowish green while the bottom part was yellowish. The diameters of both colonies were $7.35 \mathrm{~cm}$ and $8 \mathrm{~cm}$, respectively. In addition, these two isolates also had entire colon surface as well as the edges of the colony and both showed the presence of a clear exudate. The microscopic structure of both colonies was similar, in terms of their generative hyphae and fusoid spore form with size of $5.19 \mu \mathrm{m}$ and $5.39 \mu \mathrm{m}$, respectively. Moreover, the generative forms of spores and hyphae of these two isolates were also similar to isolate $\mathrm{KrC} 1$. 
The fifth isolate, $\mathrm{KrE} \mathrm{1,} \mathrm{had} \mathrm{a} \mathrm{growth} \mathrm{diameter} \mathrm{of} 2.72$ $\mathrm{cm}$ after seven days of incubation at room temperature $\left(28 \pm 2{ }^{\circ} \mathrm{C}\right)$. The color of the resulting colonies was dark green on the surface with white edge hem and cream or pale yellow at the bottom part. In addition, this isolate has undulate colony margin, irregular shape of colony form, and clear exudate. Microscopically, the generative hyphae of this isolate resembled the generative hyphae of Penicillium sp., which is characterized by biverticillate conidiophores which consist of phialide (flaskshaped) and metulae, globose conidia with ranged size 4.41-5.65 (4.92) X 4.27-5.27 (4.70) $\mu \mathrm{m}$, and septate hyphae. Saif et al. (2020) was informed that after being grown in PDA media for seven days, all fungi species of the genus Penicillium spp. had similar colony appearance although they had different species levels. In general, the colony's morphology is greenish to dark green and brownish in color, with a common microscopic structure of conidia that are chained or single, having phialide of flask-shaped or ampuliform shape, occasionally producing metulae, and hyaline conidiophores with four types of branching, namely monoverticillate, biverticillate, terteverticillate, and quarteverticillate. In addition, the conidia produced can be globose, subglobose, ellipsoidal, and cylindrical. Vico et al. (2014) reported that Penicillium sp. grown in PDA media for seven days had a colony diameter of $3.30-3.84 \mathrm{~cm}$. This finding is not significantly different to what we found in this research. In addition, the shape of the conidia is globose to subglobose with sizes ranging from 2.51-4.22 (3.38 \pm 0.49$) \times 2.35-3.61$ ( $3 \pm 0.36) \mu \mathrm{m}$, phialid with an ampuliform shape and the type of branching of the conidiophores is terverticillate.

\section{Phylogenetic of stain fungi}

The results of molecular identification are presented on phylogenetic tree (Figure 2). Isolate $\mathrm{KrC} 1, \mathrm{KrD} 1$, and KrD 2 have 99\% similarities with Paecilomyces maximus and Paecilomyces formosus, whereas isolate $\mathrm{KrC} 2$ has a $100 \%$ similarity with Aspergillus chevalieri, A. cristatus, A. intermedius, A. montevidensis, A. porosus, A. costiformis, and A. caperatus, and $\mathrm{KrE} 1$ has a $100 \%$ similarity with Penicillium crustosum. The phylogenetic analysis showed that $\mathrm{KrC} 1, \mathrm{KrD} 1$, and $\mathrm{KrD} 2$ were related to two species of fungi from the genus Paecilomyces. Based on a search on the Mycobank website and Index Fungorum as a repository of fungal specimens recognized by The International Code of Nomenclature for algae, fungi, and plants (ICN), it was revealed that Paecilomyces maximus and Paecilomyces formosus are synonymous names. After testing the ITS region genes,-tubulin and calmodulin, Samson et al. (2009) stated that Paecilomyces formosus consists of three taxa, namely $P$. formosus, $P$. lecythidis, and $P$. maximus. Microscopically, the three taxa are difficult to distinguish. However, there are several things that can distinguish $P$. maximus from other taxa, including its faster growth in malt extract agar (MEA) media at $37^{\circ} \mathrm{C}$ and different extrolites profiles from $P$. formosus. Houbraken et al. (2020) suggested the use of the name $P$. maximus instead of $P$. formosus due to the invalid explanation of $P$. formosus to its basyonym, namely Monilia formosa. Similar characteristics were also shown by isolate $\mathrm{KrC} 2$ which had similarities with seven Aspergillus species belonging to the Aspergillus section of Aspergillus. Chen et al. (2017) reported that there are three common clades of Aspergillus section Aspergillus, namely clades A. ruber, A. glabrum and A. chevalieri. Based on the phylogenetic analysis, it was revealed that the isolate $\mathrm{KrC} 2$ belonged to the clade $A$. chevalieri.

Based on these results, the stain fungi isolates that we obtained from the rubberwood are different from those found by OldertrØen et al. (2016) which were Aspergillus niger, Aspergillus flavus, and Penicillium citrinum; and also different from those found by Razali et al. (2016) which were Fusarium equiseti, Mucor irreguralis, and Lasiodiplodia theobromae. However, some results still showed similarities in genus level. Other studies also reported that Paecilomyces spp. was not only found on rubberwood, but also on various agricultural plants, including pistacio (Pistacia vera) that had dieback in Iran (Heidarian et al. 2018). Since Aspergillus section Aspergillus has wide geographical distribution, these fungi could be also found in indoor areas, such as on wooden products and foods (Chen et al. (2017). In addition, Penicillium sp. and Aspergillus sp. were also identified from laminated veneer lumber (LVL) which is made from rubberwood (Rahmawati et al. 2020), and buried archaeological woods that belonging to the genera Picea, Larix, and Pinus (Pedersen et al. 2020). Based on the references, it was revealed that $P$. formosus or $P$. maximus as $\mathrm{KrC} 1, \mathrm{KrD} 1$, and $\mathrm{KrD} 2$, and Penicillium crustosum as $\mathrm{KrE} 1$ have not been isolated from rubberwood and stored in one of Indonesia's Cultural Collections, while Aspergillus from section Aspergillus as $\mathrm{KrC} 2$ has been isolated and stored in one of the culture collections, but not derived from rubberwood. Therefore, all these isolates are considered as new record as wood-staining fungi that infected rubberwood in Indonesia. Hence, the isolates might become a potential study in the future in regard to explore more scientific information of the isolate as a basis for their control technic development.

\section{The visualization of stain fungi infestation on wood samples}

After four weeks of incubation, we found that isolate code $\mathrm{KrC} 2$ and $\mathrm{KrD} 2$ showed the highest growth rate on wood samples, which were reached $86.57 \%$ and $86.22 \%$, respectively (Table 3 ). Therefore, according to the scoring system presented in Table 1 , both of the isolates had an infestation score of 5. Meanwhile, the growth rate of isolate code $\mathrm{KrD} 1$ and $\mathrm{KrE} 1$ reached percentage growth above $50 \%$, which were $75.18 \%$, and $56.34 \%$, respectively. However, one isolate ( $\mathrm{KrC} 1)$ did not show significant growth (less than 10\%).

Table 3. Growth intensity of five stain fungi isolates on the top surface of wood samples

\begin{tabular}{lcc}
\hline Stain fungi isolates & Isolate's growth rate (\%) & Score \\
\hline $\mathrm{KrC} 1$ & 7.03 & 1 \\
$\mathrm{KrC} 2$ & 86.57 & 5 \\
$\mathrm{KrD} 1$ & 75.18 & 4 \\
$\mathrm{KrD} 2$ & 86.22 & 5 \\
$\mathrm{KrE} 1$ & 56.34 & 3 \\
\hline
\end{tabular}




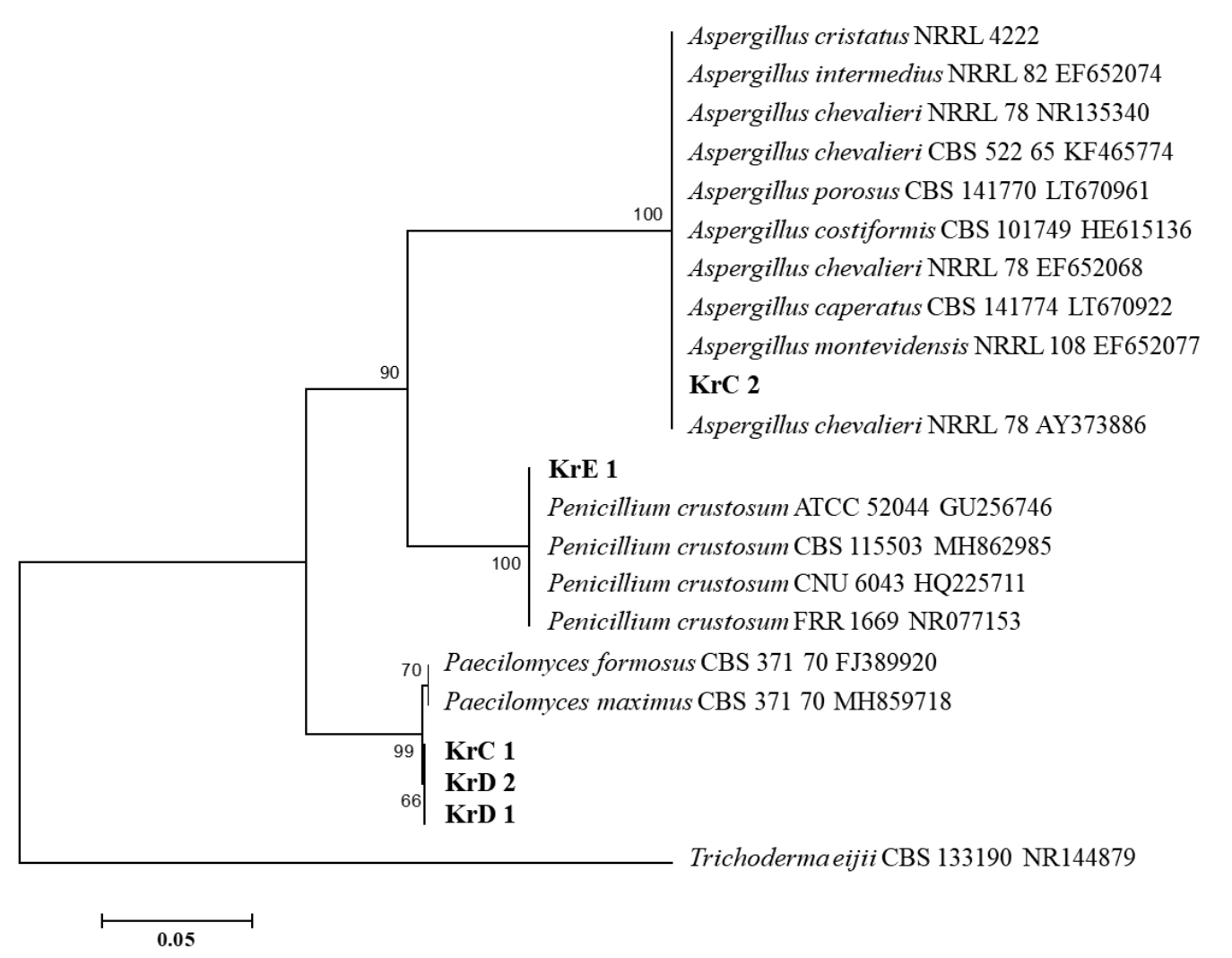

Figure 2. Phylogenetic tree of isolates $\mathrm{KrC} 1, \mathrm{KrC} 2, \mathrm{KrD} 1, \mathrm{KrD} 2$, and $\mathrm{KrE} 1$ with Trichoderma eijii as outgroup based on Neighbor Joining

Visually it seems that hyphae isolate $\mathrm{KrC} 1, \mathrm{KrD} 1$, and $\mathrm{KrD} 2$ covered the entire surface of the media, even covering some of the surface of the wood sample. In other words, the three hyphae isolates have spread and reached all the surface of the wood sample. This finding is in accordance with the fact that when the isolates are inoculated on the PDA media for morphological observations, the growth of the three isolates were much faster than the growth of $\mathrm{KrC} 2$ and $\mathrm{KrE} 1$ isolates. However, hyphae isolates $\mathrm{KrC} 2$ and $\mathrm{KrE} 1$ also covered most of the surface of the test sample. On the other side, there was no visible contamination in the control indicating that there were no other microbes staining the wood sample. Visualization of the infestation of five stain fungi isolates that had the highest staining intensity on wood samples after four weeks of inoculation is shown in Figure 3.

The staining that occurs in the test samples looked different from the colony color of each isolate. Morphologically, the isolate colonies had varied colors, from black, yellowish, to greenish, however, the coloration of the test samples was predominantly black. This happened because the color was not only caused by the color of the isolate's conidia, but also by the pigmentation of the hyphae and the activity of enzymes that reacted with the chemical components found in the wood. Valiante et al. (2016) stated that the resulting staining could be derived from hyphal pigmentation or the influence of melanin on conidia in the fungal sporulation process. Aspergillus fumigatus gives its conidia a greenish-gray color which comes from one of the types of melanin it possesses, namely dihydroxynaphthalene (DHN)-melanin. This type of melanin is produced by the activation of the $\operatorname{dev} R$ and $\operatorname{rm} A$ genes that regulate the DevR and R $\operatorname{lmA}$ proteins for transcription by binding to the $p k s P$ promoter.

The stain fungi that have been obtained probably belong to the blue stain or sap stain fungi group and not to the mold group. The discoloration of wood is caused by the melanin of fungi that persist in wood even after the fungi death. The blue stain fungi have the ability to penetrate deeper into wood compared to mold that only grows on the wood surface. It is caused by the hyphae that penetrate from the pits in wood or directly through the cells by forming boreholes (Daniel 2016). Therefore, the blue stain fungi could not be removed by brushing treatment, in contrast to mold fungi. As a result, the infected wood will potentially become a waste or must be sanded to remove the blue stain that causes reduction of the wood dimension.

The ability of stain fungi to grow on wood was caused by the presence of simple sugars and starches as a source of nutrition and lack of heartwood formation (Priyadarshan 2011). Schmidt et al. (2016) w a s informed that A. niger was able to colonize wood samples in first-week incubation depends on the condition of substrates rich in glucose and starch of 162.3 and $33.5 \mathrm{nmol} \mathrm{mg}-1$, respectively. Another study also reported that the carbohydrate content most commonly found in rubberwood is starch (Ketkakomol et 
al. 2014). Stain fungi did not attack cellulose, hemicellulose, and lignin so that high weight loss does not occur in the attacked wood. Stain fungi will reduce the economic value due to decrease in the aesthetic value of wood. Another research had stated that the presence of stain fungi on wood was increased the water absorption. The higher water sorption, the higher moisture content. Based on this condition, the higher moisture content will increase the possibility of the growth of decay fungi (Feng et al. 2014).
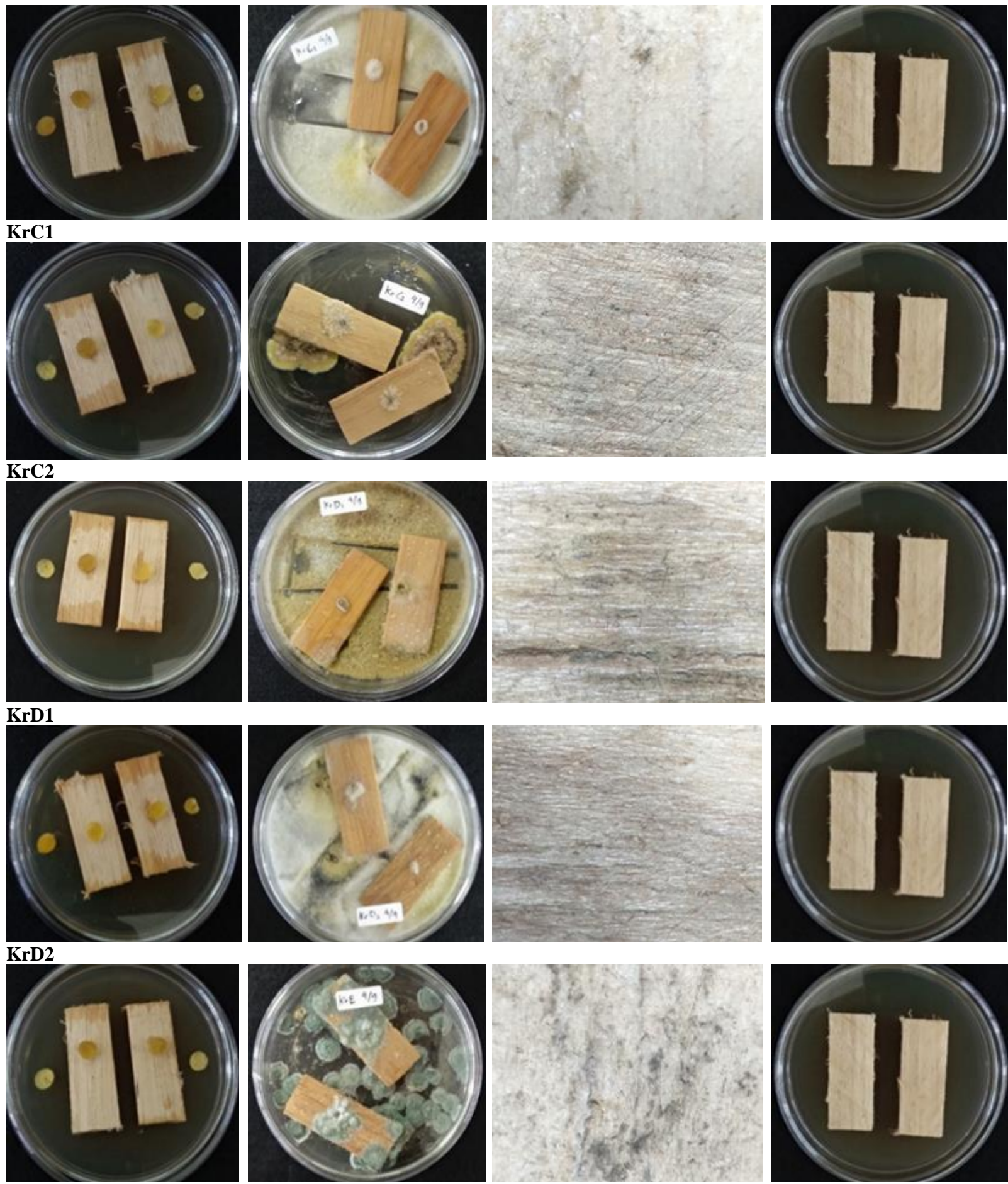

Figure 3. Visualization of the highest staining intensity of five stain fungi isolates. From left to right: wood sample before it was attacked by stain fungi, wood sample when it was attacked by stain fungi, wood sample after being attacked by stain fungi, and control 
Table 4. Discoloration on wood samples caused by five stain fungi isolates

\begin{tabular}{|c|c|c|c|c|c|c|c|c|c|}
\hline \multirow{2}{*}{ Stain fungi isolates } & \multicolumn{3}{|c|}{ Pre-inoculation } & \multicolumn{3}{|c|}{ Post-inoculation } & \multirow[b]{2}{*}{$\Delta \mathbf{E}$} & \multirow{2}{*}{ Color* } & \multirow{2}{*}{ Color description* } \\
\hline & $\mathbf{L}$ & $\mathbf{a}$ & $\mathbf{b}$ & $\mathbf{L}$ & $\mathbf{a}$ & b & & & \\
\hline $\mathrm{KrC} 1$ & 78.6 & 8 & 20.45 & 71.65 & 8.65 & 22.35 & 7.23 & & Dark grayish orange \\
\hline $\mathrm{KrC} 2$ & 81.6 & 6.65 & 19.55 & 54.35 & 10.8 & 18.15 & 27.60 & & Dark grayish yellow \\
\hline $\mathrm{KrD} 1$ & 81 & 7.2 & 21.2 & 65.85 & 7.85 & 22.35 & 15.21 & & Very Dark grayish orange \\
\hline $\mathrm{KrD} 2$ & 77.7 & 7.9 & 19.25 & 61.05 & 7.3 & 18.2 & 16.69 & & Dark grayish orange \\
\hline KrE 1 & 80.4 & 6.9 & 19.95 & 67.2 & 7.4 & 19.7 & 13.21 & & Very Dark grayish blue \\
\hline
\end{tabular}

Note: *Defined by ColorHexa (2012)

\section{Discoloration of the wood samples}

The results showed that the natural color of rubberwood (without fungal attack) was yellowish white with an average value of $\mathrm{L}=80.11, \mathrm{a}=7.23, \mathrm{~b}=20.00$, and $\mathrm{E}=$ 82.90 (Table 4). Regarding the natural color of the rubberwood, Jiang et al (2020) reported almost the same L, $\mathrm{a}$, and $\mathrm{b}$ values, which were $80.94,4.37$, and 21.69, respectively. Meanwhile, after being attacked by the stain fungi, the color changes, depending on the type of isolate of the stain fungi that attacks it.

Based on the results displayed in Table 4, color of wood samples were significantly different from each other in terms of their $\mathrm{L}$, $\mathrm{a}$, and $\mathrm{b}$ values. Quantitative staining analysis provides additional information regarding the value of color differences more accurately. Overall, the L values in all isolates seemed to decrease, indicating that there had been a change in brightness in the test samples due to fungal activity. In addition, the values of $a$ and $b$ of all test samples seemed to fluctuate, but overall it was seen that the test samples had a reddish and yellowish color which was indicated by positive values of $a$ and $b$. The difference in the $a$ and $b$ values of each test sample which increased and decreased, was allegedly due to the staining reaction between the chemical components in the form of enzymes or melanin from the isolate and the chemical components of the wood which could result in a darker or faded color.

Based on the color description in Table 4, it is known that the colors formed in the test samples were Dark grayish yellow and Dark grayish orange due to the attack of $\operatorname{KrC} 2$ and $\mathrm{KrD} 2$ isolates as isolates with the highest score. In addition, the $\mathrm{E}$ values shown by both are 27.60 and 16.69 by $\mathrm{KrC} 2$ and $\mathrm{KrD} 2$ isolates, respectively. The resulting value belongs to the highest class, which is six, or there was a very drastic color change based on Table 2. The same thing was also seen by isolates $\operatorname{KrD} 1$ and $\mathrm{KrE} 1$ with E values of 15.21 and 13.21, respectively, so they are classified into class six with very high color changes. The lowest $\mathrm{E}$ value was shown by isolate $\operatorname{KrC} 1$, which was 7.23, but based on Table 2, this value was still relatively high because it was in class 5 or there was a clear color change. All of the resulting color change values $(\Delta \mathrm{E})$ are in line with the isolate scores in Table 3.

In summary, a total of five stain fungi were successfully isolated and identified from seasoned rubberwood and two of them showed the highest growth rate on wood samples. Both isolates were identified as Aspergillus chevalieri section Aspergillus and Paecilomyces maximus or $P$. formosus belong to the group of blue stain fungi. The discoloration caused by these two stain fungi was the worst compared to the other isolates, and showed the highest significant difference compared to natural color of the rubberwood. According to publication and distribution in Indonesia culture collections, these isolates were not isolated and identified yet from rubberwood, therefore these isolates could be considered as a new stain fungi species recorded from rubberwood industry in Indonesia. Hence, these isolates might become a potential study in the future.

\section{ACKNOWLEDGEMENTS}

Acknowledgments and awards are conveyed to the Directorate of Research and Community Service, the Directorate General of Research and Innovation Strengthening, Ministry of Education, Culture, Research and Technology, the Republic of Indonesia for the funding support of this research under the contract No. 2040/IT3.L1/PN/2021.

\section{REFERENCES}

Afshari-Jouybari H, Farahnaky A. 2011. Evaluation of photoshop software potential for food colorimetry. J Food Eng 106 (2): 170-175. DOI: 10.1016/j.jfoodeng.2011.02.034.

Aleinikovas M, Varnagirytė-Kabašinskienė I, Povilaitienė A, Šilinskas B, Škema M, Beniusienè L. 2021. Resistance of wood treated with iron compounds against wood-destroying decay and mould decay. Forests 12: 645. DOI: 10.3390/f12050645.

Chen AJ, Hubka V, Frisvad JC, Visagie CM, Houbraken J, Meijer M, Varga J, Demirel R, Jurjevic Z, Kubatova A, Sklenar F, Zhou YG, Samson RA. 2017. Polyphasic taxonomy of Aspergillus section Aspergillus (formerly Eurotium), and its occurrence in indoor environments and food. Stud Mycol 88: 37-135. DOI: 10.1016/j.simyco.2017.07.001.

Christie RM. 2007. Colour Chemistry: The Royal Society of Chemistry Science Park. The Royal Society of Chemistry, Cambridge.

ColorHexa. 2012. Color Encylopedia: Information and Coneversion. Available online: https://www.colorhexa.com/ [18 October 2021]

Daniel G. 2016. Fungal Degradation of Wood Cell Walls. in: Kim YS, Funada R, Singh AP, (eds). Secondary Xylem Biology: Origins, Functions, and Applications, Academic Pr, London.

Diba K, Kordbacheh P, Mirhendi SH, Rezaie S, Mahmoudi M. 2007. Identification of Aspergillus species using morphological characteristics. Pak J Med Sci 23 (6): 867-872. 
Dong Q, Wang H, Xing X, Ji S. 2012. Identification and characterization of a special species of Paecilomyces. Ann Microbiol. 62: 1587-1592. DOI: 10.1007/s13213-011-0414-3.

Drewello R, Weissmann R. 1997. Microbiology influenced corrosion of glass. Appl Microbiol Biotechnol 47: 337-346. DOI: 10.1007/s002530050937.

Feng J, Shi Q, Chen Y, Huang X. 2014. Bluestain resistance and water absorption of wood/HDPE and bamboo/HDPE. J Appl Sci 14 (8): 776-783

Gahruie HH, Hosseini SMH, Taghavifard MH, Eskandari MH Golmakani, MT, Shad E. 2017. Lipid oxidation, color changes, and microbiological quality of frozen beef burgers incorporated with shirazi thyme, cinnamon, and rosemary extracts. J Food Qual 2017: 6350156. DOI: $10.1155 / 2017 / 6350156$

George J. 1985. Preservative treatment of bamboo, rubberwood and coconut palm-Simple methods for treating building timbers. In: Findlay WPK (ed) Preservation of timber in the tropics. Kluwer Academic, Massachusetts.

Heidarian R, Fotouhifar KB, Debets AJM, Aanen DK. 2018. Phylogeny of Paecilomyces, the causal agent of pistachio and some other trees dieback disease in Iran. PLoS One 13 (7): e200794. DOI: 10.1371/journal.pone.0200794.

Ho KS. 1999. Harvesting and log characteristics of rubberwood. In: Hong LT, Sim HC (eds) Rubberwood-processing and utilization. Forest Research Institute Malaysia (FRIM), Kepong.

Houbraken J, Konsube S, Visagie CM, Yilmaz N, Wang XC, Meijer M, Kraak B, Hubka V, Samson RA, Frisvad JC. 2020. Classification of Aspergillus, Penicillium, Talaromyces and related genera (Eurotiales): An overview of families, genera, subgenera, sections, series and species. Stud Mycol 95: 5-169. DOI 10.1016/j.simyco.2020.05.002.

Hřcková M, Koleda P, Barcík S, Štefková J. 2018. Color change of selected wood species affected by thermal treatment and sanding. Bio Resour 13: 8956-8975. DOI: 10.15376/biores.13.4.8956-8975

Hughes KA, Misiak M, Ulaganathan Y, Newsham KK. 2018. Important of psychrotolerant fungi to Antartica associated with wooden cargo $\begin{array}{lllll}\text { packaging. Antarctic Sci } 30 & \text { (5): 298-305. DOI: }\end{array}$ 10.1017/s0954102018000329.

Hunter Lab. 2008. Application Note: Hunter L, a, b color scale. Insight on Color 8 (9): 1-4.

Jantamas S, Matan N, Matan N. 2013. Effect of tangerine oil against Aspergillus niger identified from raw and boron treated rubberwood Intl J Environ Sci Develop 4 (4): 408-411. DOI: 10.7763/IJESD.2013.V4.382

Jiang H, Lu Q, Li G, Li M, Li J. 2020. Effect of heat treatment on the surface color of rubberwood (Hevea brasiliensis). Wood Res 65 (4): 633-644. DOI: 10.37763/wr.1336-4561/65.4.633644.

Junior HDJE, Ohto JM, da Silva LL, Palma HAL, Ballarin AW. 2015. Potential of rubberwood (Hevea brasiliensis) for structural use after the period of latex extraction: A case study in Brazil. J Wood Sci 62: 384-390. DOI: 10.1007/s10086-015-1478-7.

Ketkakomol S, Lerksomlan T, Clement-Vidal A, Chantuma P, Sriroth K, Liengprayoon S, Thaler P, Drevet P, Kasemsap P, Piyachomkwan K, Gohet E, Lacote R. 2014. Starch synthesis and mobilization on wood and bark of rubber tree, in relation with latek production, (1) methodological approach. Adv Mat Res 844: 15-19. DOI 10.4028/www.scientific.net/AMR.844.15.

Lim SC. Choo KT. Gan KS. Centre TT. 2003. The Characteristics, Properties and uses of plantation timbers-rubberwood and Acacia mangium. Timber Technology Bulletin No. 26. Kuala Lumpur, Timber Technology Centre, Forest Research Institute Malaysia.

Müller E, Drewello U, Drewello R, Weißmann R, Wuertz S. 2001. In situ analysis of biofilms on historic window glass using confocal lase scanning microscopy. J Cult Herit 2 (1): 31-42. DOI: 10.1016/S12962074(01)01106-2.

Oktavia F, Sahuri, Adustina DS. 2021. Progress of rubber breeding program to support agroforestry system in Indonesia. E3S Web Conf. 305 (03006): 1-8. DOI: 10.1051/e3sconf/202130503006.

Oktavia F, Lasminingsih M, Kuswanhadi. 2011. Selection of parent trees for Rubber (Hevea brasiliensis) breeding based on RAPD analysis. Nusantara Biosci 3: 124-129. DOI: 10.13057/nusbiosci/n030304
OldertrØen K, H-Kittikun A, Phongpaichit S, Riyajan S, Teanpaisal R. 2016. Treatment of rubberwood (Hevea brasiliensis) (willd. ex. a juss) Muell. Arg. with maleic anhydride to prevent moulds. J For Sci 62 (7): 314-321. DOI: 10.17221/109/2015-JFS

Pedersen NB, Matthiesen H, Blanchette RA, Alfredsen G, Held BW, Westergaard-Nielsen A, Hollesen J. 2020. Fungal attack on archaeological wooden artefacts in the Arctic-implications in changing climate. Sci Rep 10: 14577. DOI: 10.1038/s41598-02071518-5.

Pinto C, Palomar T, Alves LC, da Silva SHM, Monteiro RC, Macedo MF, Villarigues MG. 2019. Fungal biodeterioration of stained-glass windows in monuments from Belem do Para (Brazil). Intl Biodeter Biodegr 138: 106-113. DOI: 10.1016/j.ibiod.2019.01.008.

Priyadarshan PM. 2011. Ancillary income generation. In: Biology of Hevea Rubber. CABI Publishing, Wallingford.

Rahmawati N, Sumardi I, Dungani R. 2020. Isolation and identification of fungi inhabiting rubber-impregnated wood, and their role of quality changing the impregnated wood. Bioresources 15 (2): 2839-2849. DOI: $10.15376 /$ biores.15.2.2839-2849

Razali N, Azmi MMZ, Zainuddin NAIM. 2016. Isolation and characterization of microfungi isolated from rubber tree. Acta Biol Malaysia 5 (1): 1-6. DOI: 10.7593/abm/5.1.1.

Riyaphan J, Phumichai T, Neimsuwan T, Witayakran S, Sungsing K, Kaveeta R, Phumichai C. 2015. Variability in chemical and mechanical properties of Pará rubber (Hevea brasiliensis) trees. Sci Asia 41: 251-258. DOI: 10.2306/scienceasia1513-1874.2015.41.251

Sabernasab M, Jamali S, Marefat A, Abbasi S. 2019. Molecular and pathogenic characteristics of Paecilomyces formosus, a new causal agent of oak tree dieback in Iran. For Sci 65 (6): 743-750. DOI: 10.1093/forsci/fxz045.

Saif FA, Yaseen SA, Alameen AS, Mane SB, Undre PB. 2020. Identification of Penicillium species of fruits using morphology and spectroscopic methods. J Phys Conf Ser 1644: 1-10. DOI: 10.1088/1742-6596/1644/1/012019.

Salman ABA, Sudirman LI, Nandika D. 2020. Selection of stain fungi on rubberwood (Hevea brasiliensis) and its growth response against $\begin{array}{lllll}\text { chitosan. } & \text { Biodiversitas } 21 & \text { (10): 4501-4508. DOI: }\end{array}$ 10.13057/biodiv/d211005.

Salman ABA. 2020. Seleksi cendawan pewarna pada kayu karet (Hevea brasiliensis Muell. Arg.) dan responnya terhadap aplikasi kitosan. [Theses]. Institut Pertanian Bogor, Bogor. [Indonesia]

Samson RA, Houbraken J, Varga J, Frisvad JD. 2009. Polyphasic taxonomy of the resistant ascomycete genus Byssochlamys and its Paecilomyces anamorphs. Perssonia 22: 14-27. DOI: 10.3767/003158509X418925.

Schmidt O, Magel E, Frühwald A, Glukhykh L, Erdt K, Kaschuro S. 2016. Influence of sugar and starch content of palm wood on fungal development and prevention of fungal colonization by acid treatment. Holzforschung 70 (8): 783-791. DOI: 10.1515/hf-2015-0181.

Statistics Indonesia, The Republic of Indonesia. 2020. Indonesian wood export trend 2015-2019. Five years report 2015-2019. Statistics Indonesia, Jakarta.

Teoh YP, Don MM, Ujang S. 2011. Assessment of the properties, utilization and preservation of rubberwood (Hevea brasiliensis): A case study in Malaysia. J Wood Sci 57: 255-266. DOI: 10.1007/s10086-011-1173-2.

Thathana MG, Murage H, Abia ALK, Pillay M. 2017. Morphological characterization and determination of aflatoxin-production potentials of Aspergillus flavus isolated from maize and soil in Kenya. Agriculture 7 (80): 1-14. DOI: 10.3390/agriculture7100080.

Valiante V, Baldin C, Hortschansky P, Jain R, Thywiben A, Starbburger M, Shelest E, Heinekamp T, Brakhage AA. 2016. The Aspergillus fumigatus conidial melanin production is regulated by the bifunctional bHLH Devr and MADS-box RlmA transcription factor. Mol Microbiol 102 (2): 321-335. DOI: 10.1111/mmi.13462.

Vico I, Duduk N, Vasic M, Nikolic M. 2014. Identification of Penicillium expansum causing postharvest blue mold decay of apple fruit. Pestic Phytomed 29 (4): 257-266. DOI: 10.2298/PIF1404257V.

White TJ, Bruns T, Lee S, Taylor J. 1990. Amplification and Direct Sequencing of Fungal Ribosomal RNA Genes for Phylogenetics. In: Innis MA, Gelfand DH, Sninsky JJ, White TJ, editors. PCR Protocols: A Guide to Methods and Applications. Academic Pr. New York. 